\title{
Institutions, Capital Flows and Financial Integration
}

James R. Lothian

Fordham University, lothian@fordham.edu

Follow this and additional works at: https://fordham.bepress.com/crif_working_papers

Part of the Finance and Financial Management Commons

\section{Recommended Citation}

Lothian, James R., "Institutions, Capital Flows and Financial Integration" (2005). CRIF Working Paper series. 7. https://fordham.bepress.com/crif_working_papers/7

This Article is brought to you for free and open access by the Frank J. Petrilli Center for Research in International Finance at DigitalResearch@Fordham. It has been accepted for inclusion in CRIF Working Paper series by an authorized administrator of

DigitalResearch@Fordham.For more information, please contact considine@fordham.edu, dsabol@fordham.edu. 


\title{
Institutions, Capital Flows and Financial Integration
}

\author{
James R. Lothian* \\ A Keynote Address to the \\ Conference on Emerging Markets Finance \\ London, May 5-6, 2005 \\ Sponsored by \\ Cass Business School \\ Journal of International Money and Finance, \\ Economic and Social Research Council \\ European Bank of Reconstruction and Development
}

This draft May 2005

\footnotetext{
* Schools of Business, Fordham University, New York, NY 10023113 West 60th Street, New York, NY 10023; tel (212) 636_6147; fax (212) 765_5573; email: lothian@fordham.edu; jrmlothian@aol.com. I would like to thank participants in the Frank J. Petrilli Center for International Finance workshop at Fordham University for comments on the initial draft of this paper.
} 
Abstract: Institutions, Capital Flows and Financial Integration

The central focus of this paper is on capital flows from developed to less developed countries and in particular on the question of why such flows are not much larger. I first outline the theoretical arguments with regard to such flows and then go on to review the historical evidence on international financial integration more generally. I then turn to the related literature on economic development, which over the past decade has shifted its emphasis from technology and capital accumulation per se to the underlying institutional factors that affect investment. I present evidence that such factors also affect to rich-to-poor country capital flows. Good policies - pursuit of price stability, fewer direct interventions and sound institutional structures are accompanied by higher capital flows and bad policies by lower capital flows. 


\section{Introduction}

The central focus of this paper is on international capital flows, and in particular, capital flows from the developed to the less developed countries. Why are such flows not larger? The question has puzzled economists for the past four decades. What makes it especially puzzling today is the much greater degree of financial integration now than four decades ago. Adding to the puzzle is the fact - not always recognized - that at the start of the last century such flows were substantial when viewed either as a percentage of the total or relative to the incomes of the receiving countries. In the next two sections of the paper, I outline the theoretical arguments with regard to rich-to-poor country capital flows and then go on to review the historical evidence on international financial integration more generally. To try to answer the question I turn to the related literature on economic development, which over the past decade and a half has shifted its focus from technology and capital accumulation to the underlying factors affecting the returns to investment. Here government actions, both in the sense of the day-to-day policies pursued by various government agencies and central banks and the institutions like property rights that affect the basic business environment, have come to be increasingly emphasized. I then go on to present evidence that these factors also affect capital flows. Good policies - pursuit of price stability, fewer direct interventions and sound institutional structures are accompanied by higher capital flows and bad policies by lower capital flows.

\section{The Lucas-Schultz Paradox}

Robert E. Lucas, Jr., in an article of the same title (1990) asks the question "Why doesn't capital flow from rich to poor countries?" It does not, he says, but should since such poor countries lack capital when viewed by rich-country standards and, therefore, have both high marginal products of capital and correspondingly high rates of return to investment. Lucas cites 
India as a case in point. By his calculations India has a marginal product of capital that is anywhere from a high of 58 times to 5 times that of the United States, depending upon whether one allows for differences in stocks of human capital.

The paradox as Lucas states it, therefore, is that "If the neoclassical model were even close to being accurate and if world capital markets were even close to being free and complete, it is clear that in the face of return differentials of this [58 times greater] magnitude, investment goods would flow rapidly from the United States and other wealthy countries to India and other poor countries." Even if the much lower estimate of 5 times greater is more nearly correct, he goes on to say "[I]t leaves the original paradox very much alive: a factor of 5 difference in rates of return is still large enough to lead one to expect capital flows much larger than what we observe."

Two decades earlier, Theodore W. Schultz puzzled over the same question but from a rather different perspective. Schultz's take on the issue was not that the capital stock in poor countries or poor sectors was low per se. He argued to the contrary that it was, in fact, quite high. Interestingly, given Lucas's example of India versus the United States, Schultz supported this contention with data for Senapur, India. The problem, he argued, was that the physical capital in poor countries was of the wrong kind. What were needed for growth were continual investments in higher quality physical capital - in agriculture, for example, tractors rather than bullocks - and the increased human capital that would enable farmers and other workers to make use of the higher quality physical capital. Rates of return to the higher quality inputs were high while rates of return to the existing traditional inputs were low. Looked at in his way the puzzle is why investments in the higher quality inputs have in general not been made and the inflows of 
funds from abroad not been much greater. I will return to this question below. First, to provide some background to the subsequent discussion, I want to summarize what we have learned from some of the recent studies of capital-market integration.

\section{Capital Market Integration in Historical Perspective}

The literature dealing both with capital-market integration and with economic integration more generally is not only voluminous but rapidly growing. ${ }^{1}$ Three stylized facts of particular interest to the question at hand have emerged from these studies. The first is that financial integration today is much greater than it was thirty years ago and quite probably greater than even ten years ago. The second is that despite these increases it has only recently returned to the level at which it stood during the heyday of the gold standard in the decades preceding World War I. The third is that the time pattern of integration has differed greatly between developed and less developed countries. A century ago, there were substantial capital flows from the developed core to the less developed periphery; today those flows are small.

Figure 1, which I have taken from some of my earlier work (Lothian, 2002), illustrates the first two stylized facts. Shown in the two panels of Figure 1 are plots of cross-country standard deviation of quinquennial averages of ex-post short-term and long-term real interest rates for varying groups of developed countries chosen according to data availability.

In the standard Fisherian framework (see in particular, Fisher, 1907, pp. 279-280), the real rate of interest is the real rate of return on physical assets - in Fisher's terminology the

1 Contributions to this literature have come from researchers in a variety of sub disciplines of economics - macroeconomics, international finance, finance more generally and economic history. Recent books on the subject include Obstfeld and Taylor (2004), O'Rourke and Williamson (1999), and Bordo and Taylor, ed. (2003). See Bekaert, et al. (2003) for a review of some of the relevant finance literature. 
"commodity rate of interest." It and the real rate of interest on financial assets are linked via an arbitrage relationship. Using this framework, we can view the cross-country differential in real returns on financial assets as being composed of two components: the differential in real rates of return on physical assets and the (two) within-country differentials between real interest returns on physical assets and on financial assets:

$$
\rho_{\mathrm{t}}-\rho_{\mathrm{t}}^{\mathrm{F}}=\left[\rho \kappa_{\mathrm{t}}-\rho \kappa_{\mathrm{t}}^{\mathrm{F}}\right]+\left[\left(\rho_{\mathrm{t}}-\rho \kappa_{\mathrm{t}}\right)-\left(\rho_{\mathrm{t}}^{\mathrm{F}}-\rho \kappa_{\mathrm{t}}^{\mathrm{F}}\right]\right.
$$

where $\rho_{\mathrm{t}}$ and $\rho_{\mathrm{t}}^{\mathrm{F}}$ are the ex ante real interest rates on financial assets, $\rho \kappa_{\mathrm{t}}$ and $\rho \kappa_{\mathrm{t}}^{\mathrm{F}}$ are the real returns on the physical assets in the two countries and the superscript $F$ denotes the foreign country. The first term on the right-hand side reflects the degree of arbitrage across countries; the second, the degree of financial intermediation within the two countries.

Writing this equation in terms of anticipated rather than actual rates of inflation, we get:

$$
r_{t}-r_{t}^{F}==\left[\rho \kappa_{t}-\rho \kappa_{t}^{F}\right]+\left[\left(\rho_{t}-\rho \kappa_{t}\right)-\left(\rho_{t}^{F}-\rho \kappa_{t}^{F}\right]+\left(\left[\pi_{t}^{*}-\pi_{t}^{*}\right]-\left(\left[\pi_{t}-\pi_{t}^{F}\right]\right)\right.\right.
$$

where $r_{t}-r_{t}^{F}$ is the differential in ex post real interest rates, and $\left(\left[\pi_{t}^{*}-\pi_{t}^{*}\right]-\left(\left[\pi_{t}-\pi_{t}^{F}\right]\right)\right.$ is the relative differential between anticipated and actual inflation rates. In the comparisons that follow, I use the current rate of inflation as a proxy for the anticipated rate. In large samples, given rational expectations, errors associated with this measure will tend toward zero. For this reason I use quinquennial averages of the data. 
During the course of the nineteenth century, the standard deviations of both real bond yields and real short-term interest rates decreased and in most instances remained low until the start of World War I. The pattern, however, began earlier and was more pronounced for the smaller groups of countries than for the larger. The degree of market integration, therefore, varied both over time and across countries at given points of time - more countries becoming more integrated as time elapsed. The integration process, however, was not at all continuous. The degree of interest rate divergence rose dramatically with the onset of World War I, fell off somewhat during the early Interwar Years, but then rose again during the Great Depression, and remained high throughout World War II and the years immediately thereafter. Only as the postWorld War II period wore on have we seen a return to levels in the same general range as those observed under the gold standard. This tendency, moreover, appears to have strengthened in very recent years (Goldberg et al., 2003).

In broad outline, the same pattern is visible in other indicators of financial integration. It is not, therefore, simply an artifact of the real-interest-rate data. Equity returns (Lothian, 2002; Obstfeld and Taylor, 2002), quantity indicators such as capital flows and stocks of foreign assets (Lothian, 2000; Obstfeld and Taylor, 2004), Feldstein-Horioka savings-retention coefficients (Obstfeld and Taylor, 2004), and trade flows (Grassman, 1980; Lothian, 2000) all tell a similar story to that of real interest rates. In each instance, the classical gold standard period from 1880 to 1913 shows substantial integration, the period from 1913 until 1945 a substantial reversal, and the period thereafter a gradual return to integration.

It is clear from these data, therefore, that major wars and economic disruptions on the scale of the Great Depression have as one of their by-products complete disruptions of trade in both goods and securities. We also see this in the data for the early part of the period shown in 
Figure 1, the Napoleonic War years and the years immediately following, and again during the period of the US Civil War. Integration has, however, been the norm - the central tendency so to speak - for centuries and indeed even millennia as I have argued elsewhere (Lothian, 2002). What has differed through time, and not at all surprisingly, given the substantial temporal differences in transactions costs and the speed of information flows, has been its scale in absolute terms and its geographical scope.

Figure 2 contains a plot similar to Figure 1, but for an expanded sample of 83 countries over the shorter period 1970-2003. The data again are cross-country standard deviations of quinquennially averaged annual ex-post real interest rates, in this instance, short-term interest rates alone. I have computed these for four country groups: the OECD; the OECD and AsiaPacific; the OECD, Asia-Pacific and Latin America-Caribbean; the OECD, Asia-Pacific, Latin America-Caribbean and Africa.

Three features of the chart stand out. The first is the increased cross-country divergence in real interest rates that results in each instance as the three non-OECD groups are added sequentially. For the OECD group we see a level of divergence roughly the same as in Figure 1 over this period. It then increases with the addition of Asia, increases further with the addition of Latin America and increases much further still with the addition of Africa. The second is the decline in the cross-country divergence observed for the OECD countries and for the OECD plus Asia during the last decade and a half relative to earlier. The third is the progressive narrowing of real-interest rate divergences in the case of the OECD versus Asia and the lack thereof for the OECD versus the other two groups.

The major inferences to be drawn are that integration has been, and for the most part still 
is, much less complete for the periphery vis-à-vis the OECD core, that this is changing for countries in Asia, and I would guess may also be changing for some countries in Latin AmericaCaribbean, and that it is not changing for countries in Africa. How much of this is the result of actual barriers in the form of controls of various sorts and how much is due to country risk is impossible to separate out. ${ }^{2}$

Quantity data tell very much the same story with regard to recent years as the real-interest data. We can see this in the two panels of Figure $3 .^{3}$ Shown in Figure $3 a$ is the distribution of gross stocks of foreign investment as shares of the total in both 1913 and 1997 for country groups arrayed according to per capita income relative to the United States. For 1997, 82 per cent of the foreign capital investment stocks were in countries with levels of income that were 60 per cent or greater that of the United States. Countries with income levels 40 per cent or less had a share of only 14 per cent of the total. For 1913, the situation is almost the exact opposite. Countries with incomes 40 per cent or less that of the United States had a 50 per cent share of the total and countries with income 60 percent or more that of the United States had a 46 per cent share. Shown in Figure $3 \mathrm{~b}$ is a similar chart with the distribution of the ratios of average foreign capital to GDP. For the two highest relative income quintiles, these averaged 45 per cent in 1997; for the two lowest, 13 per cent. The corresponding figures for 1913, in contrast, were 10 per cent and 20 per cent respectively.

\section{Economic Growth and the Lucas-Schultz Paradox}

2 Daniel Peter Fedeyko (2005) uses the Fraser Institute's index of the Economic Freedom of the World (EFW) that I use below to investigate the role of country risk in this data set. He finds a significant positive relation between EFW and the spreads between less-developed-country and developed-country real interest rates over the period 1995-2002.

3 Alan Taylor graciously provided these data. 
Closely related to the question of why capital does not flow from rich to poor countries is the question of why poor countries do not grow much more rapidly. In the neoclassical model, capital flows and real-income convergence are two aspects of the same process. As an empirical matter, however, we do not find a tendency toward convergence in this absolute sense, but only a form of relative convergence (Barro and Sala-i-Martin, 1992).

A standard way of approaching the question of economic growth is via growth accounting. The usual growth-accounting equation takes the form:

$$
d y=s_{L} d L+s_{K} d K+R \text {, }
$$

where dy is the change in the log of real output $\mathrm{dL}$ is the change in the log of the labor force, $\mathrm{dK}$ is the change in log of the capital stock, $\mathrm{sL}$ and $\mathrm{s}_{\mathrm{K}}$ are the shares of the two factors and $\mathrm{R}$ is the measured residual, the part of dy that is unexplained by the weighted growth rates of $\mathrm{L}$ and $\mathrm{K}$.

The question of interest has been the relative contribution of the two inputs, $\mathrm{K}$ and $\mathrm{L}$, to growth. The presumption when the growth-accounting literature was in its infancy was that in the absence of measurement error $\mathrm{R}$ would be zero and the contributions of $\mathrm{K}$ and $\mathrm{L}$ would sum to one. As it turned out this, was not the case. In most of these exercises, $\mathrm{R}$, the residual, was positive and fairly substantial, often exceeding the contribution of one or the other input separately and at times the contributions of both.

Initially, explanations of what $\mathrm{R}$ represented centered around two factors: technological improvements and human capital accumulation. Later R came to be interpreted as total factor productivity (TFP). Schultz (1964) argued that technological improvements and human capital 
accumulation were simply different sides of the same coin. Both amounted to improvements in the quality of the conventional labor and capital inputs, technical change in Schultz's schema entailing an improvement in the quality of $\mathrm{K}$ and human capital accumulation an improvement in the quality of L. The two, he argued further, went hand in glove economically. Increases in the quality of the human agent due to better formal education, on-the-job training and information with regard to how to use the improved physical capital inputs - agricultural extension efforts and the like - were necessary for farmers and other workers to put the new physical capital to effective use. Standard growth models, Schultz (1964, p.73) averred, were "not designed to consider the differences in levels of the rates of return to incentives to investment and growth." One of the reasons is that "the profitability of new classes of factors of production has been concealed under 'technical change.' " The many students and colleagues whom Schultz influenced set about investigating these issues. ${ }^{4}$

Arnold C. Harberger in his presidential address to the American Economic Association focused directly on the issue of rates of return and incentives to invest. In this context, Harberger went on to make a point very similar to that of Schultz. Conventional labels for R, Harberger argued, should be replaced. A better way of viewing R was in terms of "real cost reduction" rather than "technical change" or "TFP."

We might play Juliet and ask "What's in a name?" Harberger's answer - which would have made any scholastic realist philosopher proud - is that names do in fact matter. Technical change, Harberger says "makes most economists think of inventions, of the products of research and development ....and of what we might call technical innovations." TFP, for its part "once

\footnotetext{
${ }^{4}$ See the discussion in Nerlove (1999) and the references cited therein.
} 
purged of the changes in the quality of labor and/or the direct contributions of human capital, makes one think of externalities of different kinds." Real cost reduction, in contrast, "makes one think like an entrepreneur, or a CEO, or a production manager," and hence - my phrase not Harberger's - focus directly on human behavior at the microeconomic level.

If so, thinking in terms of real cost reductions, enables us to peel the onion a step further and ask the next logical question of set of questions: What factor or factors typically account for these real cost reductions? Why do those factors operate more strongly during some time periods and in some places than in others?

Harberger's answer is in terms of economic incentives and the government policies and societal institutions that affect them for better or worse. Good policies - price stability, an absence of distorting government intervention at the levels of the firm and the household, open international trade and the like - and good institutions, the enforcement of private property being key - enable growth. They offer the entrepreneur the incentive to engage in activities that reduce real costs. They also raise the rate of return to investment and thus increase income via that channel. Bad policies and bad societal institutions have reverse effects.

The impact of institutional factors on growth has been the theme of a much other literature in recent years ranging from Douglass North's historical treatments (e.g., North), to DeSoto's (2000) descriptive account of the day-to-day difficulties entrepreneurs faced in developing countries, to econometric investigations of various sorts (e.g., Barro, 1998).

I would like to focus briefly on one of these latter contributions since it is particularly germane to what I go on to do in this paper. This is the cross-country econometric study by James D. Gwartney, Randall G. Holcombe, and Robert A. Lawson (GHL), "Economic Freedom, 
Institutional Quality, and Cross-Country Differences in Income and Growth" (2004). Two of these authors, Gwartney and Lawson, have been responsible for compiling the Fraser Institute's Economic Freedom of the World Index (EFW) which figures prominently in GHL. ${ }^{5}$

The EFW index is made up of five component indices: size of government, legal system and property rights, sound money, freedom to trade internationally, and regulation. Each of these sub indices, in turn, has anywhere from three to eighteen components. The scale of the index and its component and subcomponent indices is one to ten, with ten being indicative of the maximum degree of economic freedom.

GHL use the EFW index as a regressor in a series of cross-country regressions along with other variables common in the growth literature as controls to investigate the impact of policies and institutions on both on the level of real per capita GDP and its rate of growth. In all instances, they report statistically significant and economically meaningful EFW effects. They then go on to run similar regressions for the per-worker stocks of physical and human capital, the rates of change of both and the ratios of investment and foreign direct investment to GDP. Here they generally also find significant effects. They therefore rerun their real GDP growth regressions using residuals from these latter regressions in place of the actual variables as regressors. Allowing for both the direct and indirect EFW effects in this way increases the estimated EFW impact substantially.

\section{Policies, Institutions and Capital Flows}

5 See Gwartney and Lawson (2004) for a description of the index and for additional results to those discussed here. See Hanke and Walters (1997) for comparison of the EFW index with the alternative indices compiled by the Freedom House, the Heritage Foundation, the International Institute for Management Development and the World Economic Forum. 
A logical extension of the GHL approach is to capital flows. The degree of financial integration as a general phenomenon is at a level at least as great and most likely much greater than it was in the highly integrated world of the classical gold standard. Yet capital flows from rich countries to poor countries, which theory suggests ought to be substantial, are small in comparison to flows in the earlier period and smaller still in comparisons to flows among the rich countries themselves. Divergences in real interest rates, moreover, are substantially greater for rich vs. poor countries than rich countries vs. one another, which in turn is suggestive of both of impediments of various sorts to foreign investment in poor countries and/or substantial country risk. In short, institutional factors appear to matter.

I investigate the possible impact of such factors using the EFW index and data from Lane and Milesi-Ferretti (2001). Shown in Figure 4a is the distribution of foreign investment to GDP averaged to the countries' EFW score. These data are for a sample of 64 developed and less developed countries in the year 1997. The differences among the three country groups are clearly substantial and of the right ranking, countries with higher EFW scores being the recipients of higher foreign capital investment. A similar chart (not shown) in which the foreign investment figures are scaled by population rather than income shows essentially the same thing. Regressions of these two alternate measures of foreign capital investment, which are reported in Table 1, show positive and highly significant relationships to the EFW index in both instances.

One obvious potential problem with these results is separating the effects of economic development and institutional quality, given the links between the two both statistically and economically. One solution to the problem is to focus on the less developed countries as a group. I do this using Word Bank data for foreign direct investment (FDI) in U.S. dollars for the 
years 1997-2001 for a sample of 85 less developed countries, including members of the former Soviet bloc. I scaled the FDI figures by population. A frequency distribution of these data is shown in Fig. 4b. Regression results are reported in Table 1. Again the effect of EFW is significant and the broader picture painted by the chart indicative of substantial differences among the three groups of countries. ${ }^{6}$

The latter, as also the previous chart, provide what I regard as the most telling evidence in favor of the explanation that I have advanced. Measurement errors in the data that I have used have got to be exceedingly large. They would, I suspect, swamp small differences in the measured EFW index. Averaging the data is the classic method of dealing with such errors. The fact that when I do so the relationship is strong is, therefore, comforting. Unfortunately, however, such averaging leaves us with very few degrees of freedom.

\section{Conclusions}

Let me return to the question with which I started - why capital flows to poor countries remain so sparse. Savers in rich countries, it seems, should be taking much greater advantage of the high returns that in principle should await them. Certainly this was the case a century ago. I have argued that the reason it is not happening now is due to the institutions that are in place and the policies that have been pursued in many if not most poor countries if not continuously more than very intermittently for decades. In this regard, the emerging market countries are, I believe, the exception that proves the rule.

\footnotetext{
${ }^{6}$ For additional corroborating evidence see Alfaro, et al., 2003.
} 


\section{References}

Alfaro, Laura, Areendam Chanda, Sebnem Kalemli-Ozcan, and Selin Sayek. "Why Doesn't Capital Flow from Rich to Poor Countries?: An Empirical Investigation," unpublished working paper, University of Houston, 2003..

Barro, Robert J. Determinants of Economic Growth, Cambridge, MA: MIT Press, 1997.

Barro, Robert J and Xavier Sala-i-Martin. "Convergence," Journal of Political Economy, April 1992, 100, pp. 223-252.

Bekaert, Geert, Campbell R. Harvey and Christian Lundblad. "Equity Market Liberalization in Emerging Markets," Federal Reserve Bank of St. Louis Review July/August 2003, 85, pp. 53-74,

Bordo, Michael D. Alan M. Taylor and Jeffrey G. Williamson, eds. Globalization in Historical Perspective, Chicago: University of Chicago Press for the NBER, 2003.

De Soto, Hernando. The Mystery of Capital, New York: Basic Books, 2000.

Easterly, William. The Elusive Quest for Growth, Cambridge, MA: MIT Press, 2001.

Fedeyko, Daniel Peter. "Economic Freedom and Short-term Real Interest Rate Premia in Less Developed Countries," unpublished senior honors thesis, College of Business Administration, Fordham University, 2005.

Fisher, Irving. 1962. The Rate of Interest. [Reprint of the 1907 edition with a new introduction by Donald Dewey]. Garland Publishing, New York.

Goldberg, Lawrence, James R. Lothian and John Okunev. "Has International Financial Integration Increased,” Open Economies Review, July 2003.

Grassman, Sven, "Long-Term Trends in Openness of National Economies," Oxford Economic Papers, March 1980, 32: pp. 123-133.

Gwartney, James D., Randall G. Holcombe, and Robert A. Lawson. "Economic Freedom, Institutional Quality, and Cross-Country Differences in Income and Growth," Cato Journal, Fall 2004, 24, pp. 205-233. 
Gwartney, James D., Robert A. Lawson, Economic Freedom of the World, 2004 Annual Report, Vacouver, B.C.: The Fraser Institute, 2004.

Hanke, Steve H. and Stephen J.K. Walters, "Economic Freedom, Prosperity and Equality: A Survey," Cato Journal, Fall 1997, 17, pp. 205-233.

Harberger, Arnold. "A Vision of the Growth Process," American Economic Review, March 1998, 88, pp. 1-32.

Lane, Philip R., and Gian Maria Milesi-Ferretti. 2001. "The External Wealth of Nations: Measures of Foreign Assets and Liabilities for Industrial and Developing Countries." Journal of International Economics, 55: 263-94.

Lothian, James R. "Capital Market Integration and Exchange-Rate Regimes in Historical Perspective," Research in Banking and Finance, 1, 2000.

Lothian, James R. "The Internationalization of Money and Finance and the Globalization of Financial Markets," Journal of International Money and Finance, November 2002.

Lucas, Robert E., Jr. "Why Doesn't Capital Flow from Rich to Poor Countries?" American Economic Review, 1990, 80, pp. 92-96.

Nerlove, Marc. Transforming Economics: Theodore W. Schultz 1902-1998, In Memoriam, Economic Journal, November 1999, 109, pp.F726-F749.

North, Douglass C. Institutions, Institutional Change, and Economic Performance. Cambridge: Cambridge University Press, 1990.

Obstfeld, Maurice and Alan M. Taylor. "Globalization and Capital Markets." in Globalization in Historical Perspective, Michael D. Bordo, Alan M. Taylor and Jeffrey G. Williamson, eds. Chicago: University of Chicago Press for the NBER, 2003.

Obstfeld, Maurice and Alan M. Taylor. Global Capital Market: Integration, Crisis, and Growth. Cambridge: Cambridge University Press, 2004.

O’Rourke, Kevin H. and Jeffrey G. Williamson, Globalization and History: The Evolution of a 
Nineteenth-Century Atlantic Economy, Cambridge, MA: MIT Press, 1999.

Schultz, Theodore W. Transforming Traditional Agriculture. New Haven: Yale University Press, 1964.

Taylor, Alan M. "Globalization, Trade, and Development: Some Lessons from History." in Bridges for Development, Robert Devlin and Antoni Estevadeordal, eds. Washington, DC: InterAmerican Development Bank, 2003.

Taylor, Alan M. "Latin America and Foreign Capital in The Twentieth Century: Economics, Politics, and Institutional Change," in Political Institutions and Economic Growth in Latin America, Stephen Haber, ed. Stanford: Hoover Institution Press, 2000. 
Table 1. Cross-country regressions: Measures of foreign capital stocks on EFW index

\begin{tabular}{|l|r|r|r|r|r|}
\hline Dependent variable & Nobs & Constant & EFW & RSQ & SEE \\
\hline Ratio of net for. invest. to population & 64 & -23360 & 4038 & 0.224 & 7356 \\
\hline & & -3.604 & 4.236 & & \\
\hline Ratio of net for. invest. to GDP & 64 & -0.699 & 0.135 & 0.184 & 0.279 \\
\hline & & -2.840 & 3.736 & & \\
\hline & & & & & \\
\hline Ratio of FDI to population & 84 & -207.2 & 48,5 & 0.147 & 103.8 \\
\hline & & -2.710 & 3.760 & & \\
\hline
\end{tabular}


Fig. 1a. Real long-term interest rates, standard deviations of 5-year averages, 1800-2000

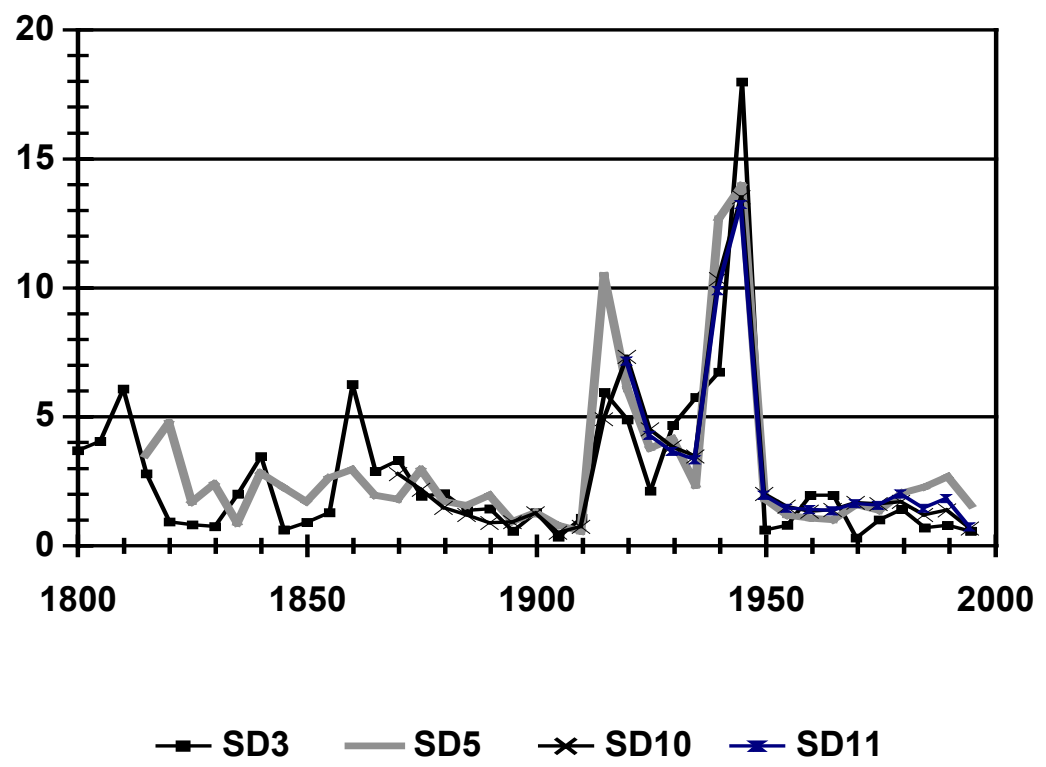

Fig. 1b. Real short-term interest rates, standard deviations of 5-year averages, 1800-2000

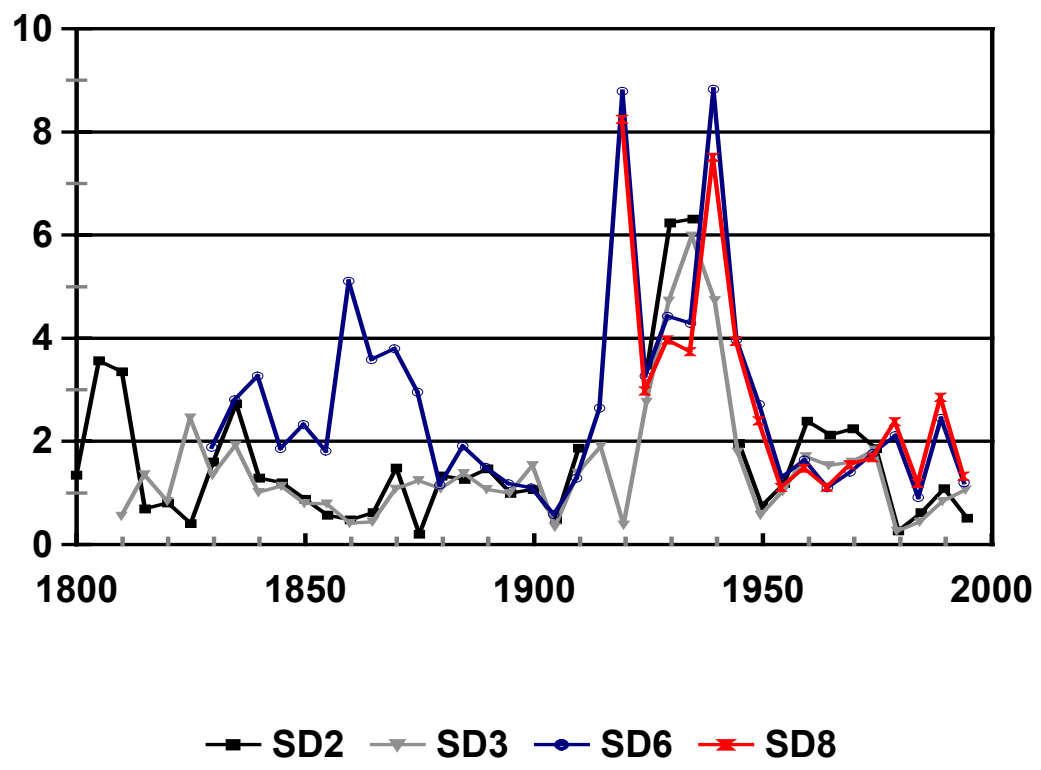


Fig. 2 Real short-term interest rates, standard deviations of 5-year averages for 89 countries, $1970-2003$

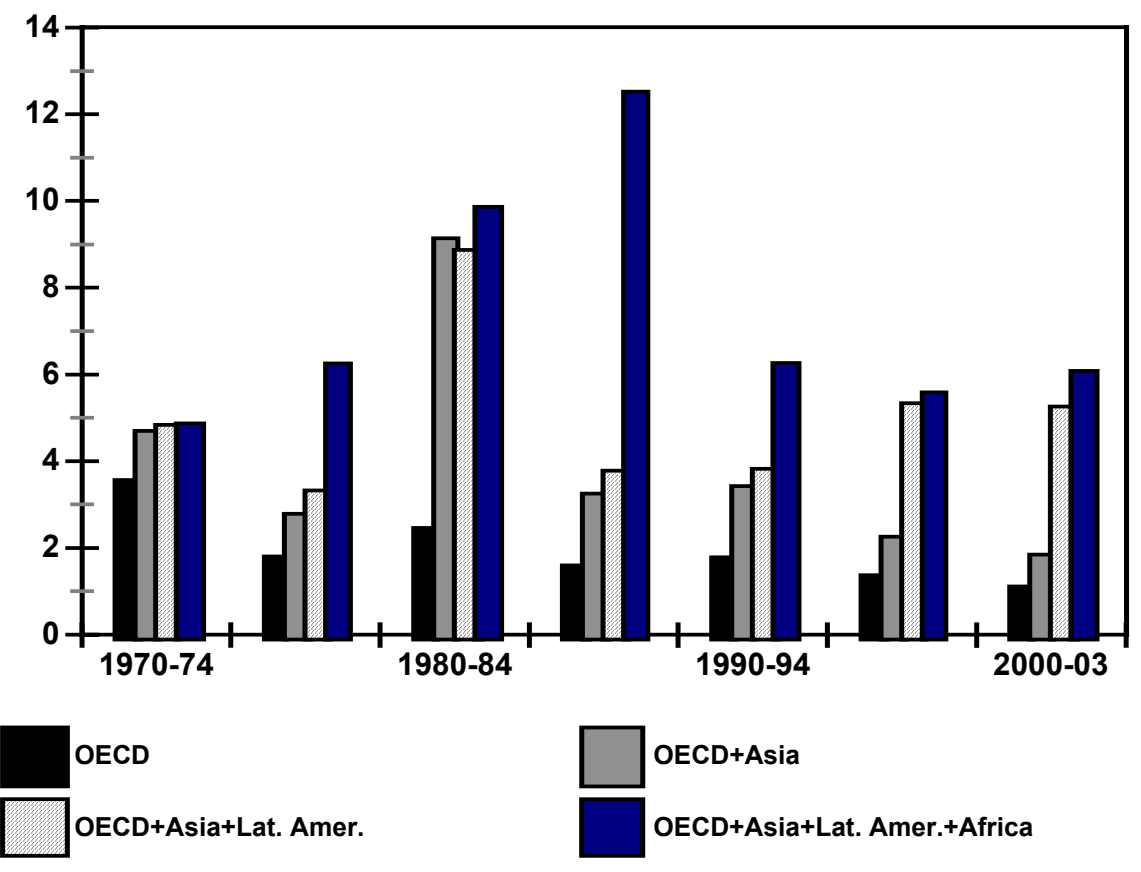


Fig. 3b. Distribution of shares of world stock of foreign investment capital by level of receiving country income per capita $(U S=100)$

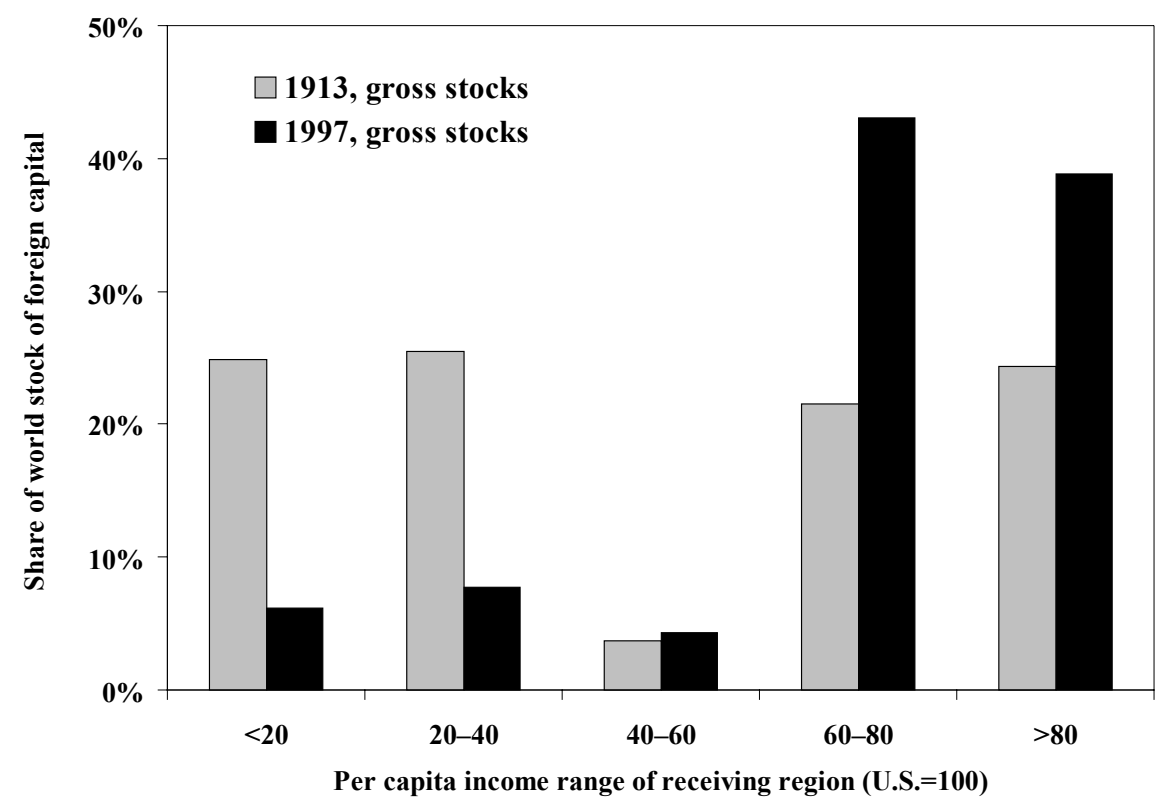

Fig. 3b. Distribution of ratios of foreign investment capital to GDP by level of receiving country income per capita (US=100)

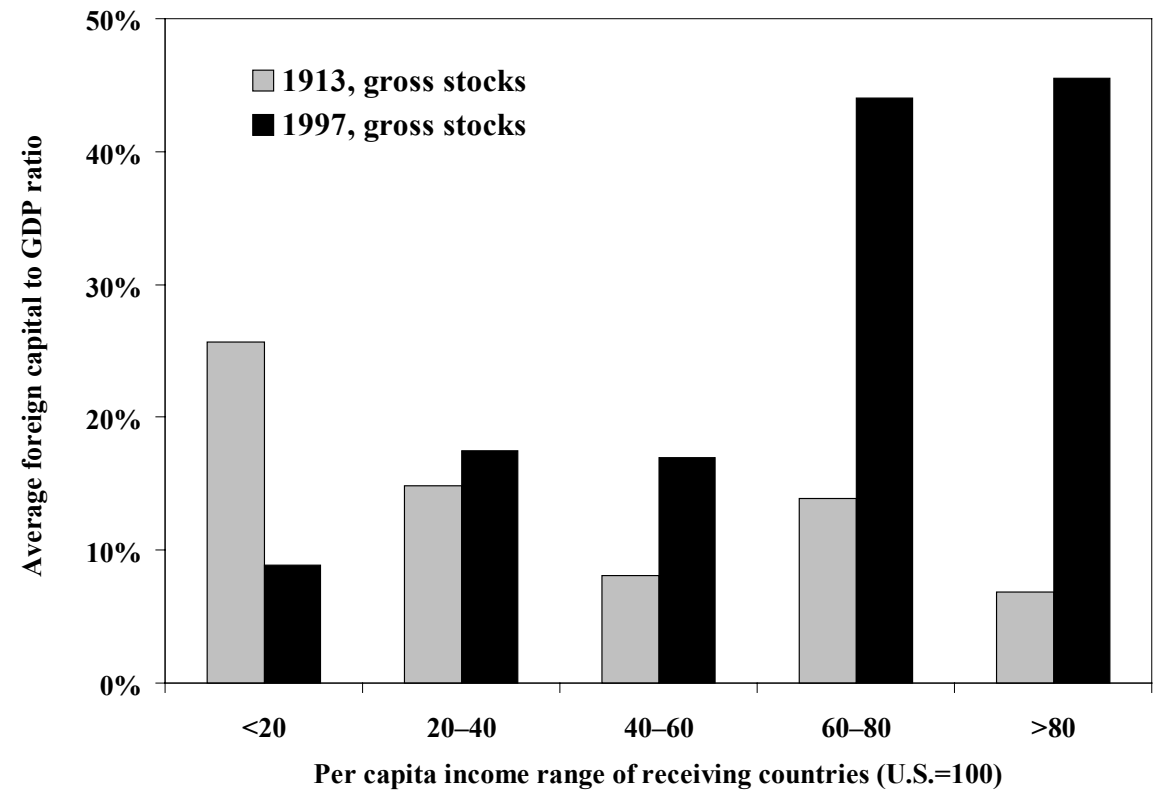


Fig. 4a. Distribution of foreign investment to GDP in 1997 by level of EFW index

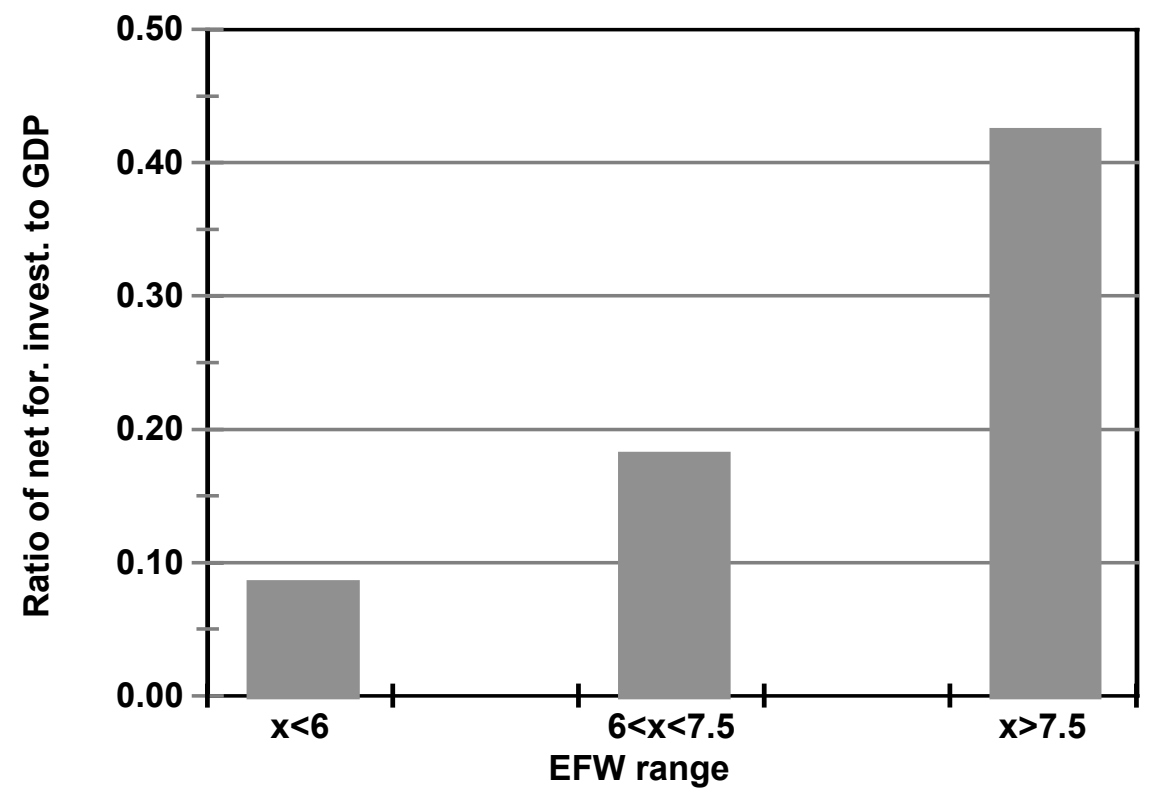

Fig. 4b. Distribution of per capita foreign direct investment in 1997-2001 by level of EFW index

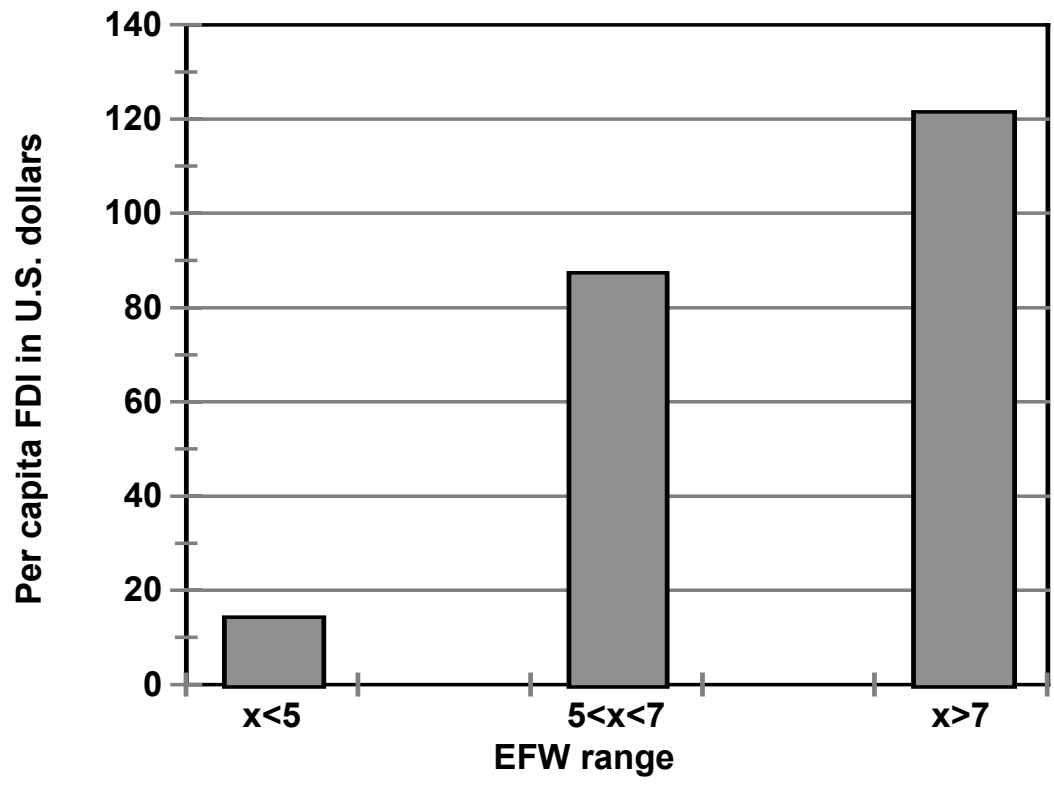

